\title{
THE CONCEPT AND CONSTRUCTION OF THE ENGINE TEST BED FOR EXPERIMENTS WITH A MULTI-FUEL CI ENGINE FED WITH CNG AND LIQUID FUEL AS AN IGNITION DOSE
}

\author{
Maciej Mikulski, Sławomir Wierzbicki \\ University of Warmia and Mazury in Olsztyn \\ Faculty of Technical Sciences \\ Stoneczna Street 46A, 10-710 Olsztyn \\ tel.: 8952451 50,fax: 895245101 \\ e-mail:maciej.mikulski@uwm.edu.pl,slawekw@uwm.edu.pl
}

\begin{abstract}
The experiments described in the article aimed at adjusting the engine test bed, its equipment and software to perform comprehensive tests on a dual-fuel spontaneous combustion engine with the main gas dose (methane or biogas) and a liquid fuel ignition dose.

The steps undertook during the tests included installing a new engine on the engine test bed, installing its equipment and preparing a dual-fuel feed system. The toxic emissions analysis system was also modified, thanks to which a thorough research based on current test methods was possible. All measurement devices were integrated and are governed by one system of data acquisition and controlling, which ensures repeatable testing conditions.

In order to exercise better control over the oil pilot dose injection, the previously used engine was replaced with a Common Rail one, which facilitates better control over the pilot dose injection and ensures controlling the system through an external driver.

Providing the engine with a set of measurement systems makes it possible to test it not only with reference to its power and toxic emissions into the atmosphere, but also to the heat absorbed by the cooling system, which enables testing engines for cogeneration units.
\end{abstract}

Keywords: combustion engines, CI engines, engine test bed, multi-fuel engine, CNG

\section{Introduction}

The preliminary research conducted in the Chair of Mechatronics at the University of Warmia and Mazury into the dual-feed system of diesel engines proved that the main problem in this kind of systems consists in ensuring engine performance at the same time minimizing the use of liquid mineral fuels [6, 8-11]. The currently applied electronic injection systems facilitate precise control over the appropriately small liquid fuel injection doses $[11,18]$. Currently known and applied feed strategies in multi-fuel engines should be modified. Contributions of fractions of particular fuels to the overall energy output should be set aiming at minimal exhaust toxicity and maximal engine efficiency. These parameters should be regulated depending on the rotational speed and engine load in order to ensure optimal use of the engine capacity $[1,4,13-15]$. With such a feed strategy, it is not easy to choose an appropriate control algorithm. Modern spontaneous combustion engines with electronic control ensure better regulation options and thus it is believed that the development of dual-feed diesel engines should be based on Common-Rail systems [10, 17].

Both the quantity of injected fuels as well as ignition advance angle should be regulated $[3,5-8)$. Moreover, there are ideas to introduce additional parameters into the control algorithms to control engine performance. A lot of researchers emphasize a chance to improve the efficiency of multi-fuel supercharged engines by controlling (throttling) the quantity and temperature of the delivered air $[5,7,8,11]$. With reference to minimizing the pilot dose, multi-fuel systems control algorithms must take into account gas composition $[7,8,12,17]$. 
The concept of multi-fuel engines is still an innovative idea, thus arriving at optimal control algorithms requires further theoretical and experimental research. Verifying the newest theories concerning multi-fuel feed systems is possible only if alterations in both the engine and the test bed equipment are introduced.

\section{The engine test bed characteristics and its modernization}

Since 2009, the Chair of Mechatronics at the UWM have owned an AVL engine test bed, where research has been performed into spontaneous combustion engines adjusted to dual-feed systems. All the equipment and subsystems of the bed are located in two separate rooms to ensure safety and comfort. The control room houses a controller seat as well as the PUMA Open system of test results automation and the controls of most of the devices. A mechanical part was installed on the engine test bed (a brake connected with the analyzed object), accompanied by the essential systems (a fuel, gas, anti-fire and cooling system) and equipment:

- a rotational speed control system THA100,

- a fuel consumption measurement system, AVL 735S fuel mass flow meter,

- a air flow measurement system (a flow meter, filter, and measurement track),

- an opacimeter to measure exhaust gas opacity.

A test bed with such specification was already described in detail in previous publications of the Chair of Mechatronics $[9,10]$.

a)

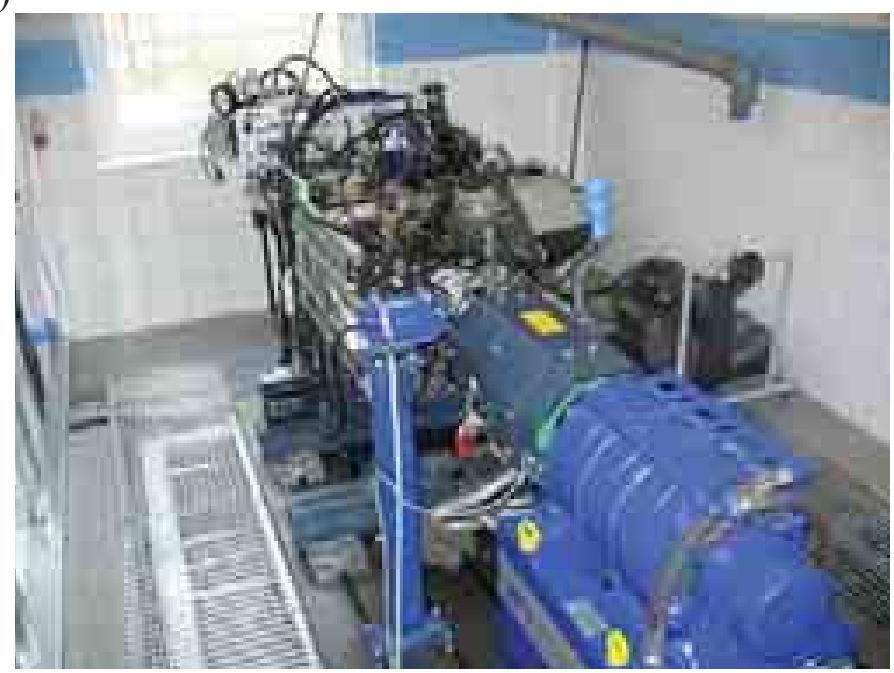

b)

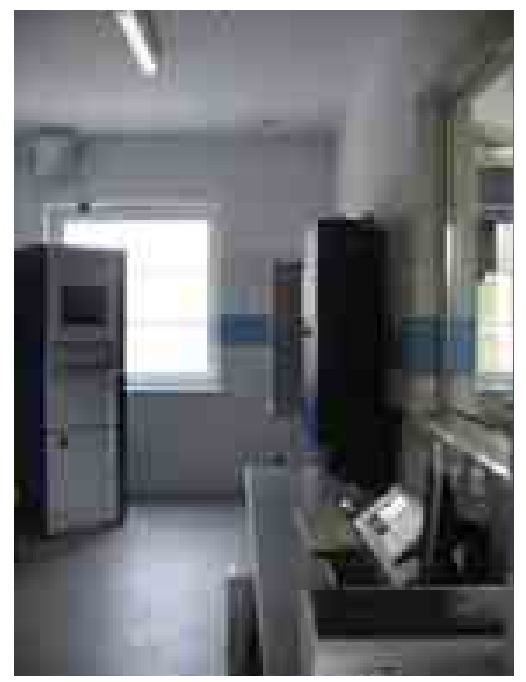

Fig. 1. The test bed; A- the room with a visible brake and the analyzed object. B - the control room with the controller's panel.

To meet the requirements of the most recent concepts in the field of multi-fuel engine research it was necessary to alter both the analyzed object (the previous VW 1.9 TDI engine adjusted to dual-fuel performance did not ensure exact dosage of fuel) as well as the test bed available to the research team. In the previous specification, the test bed made it possible to measure exhaust gas opacity, which is highly insufficient in the context of emission efficiency of modern CI engines and forces researchers to equip the test bed with exhaust analysis systems.

Modernizing the engine test bed in line with the presented criteria it was planned to:

- install and measure the new Common-Rail CI engine,

- modernize the exhaust analysis system and equip it with a new function of measuring particulate (AVL Smart Sampler),

- modernize the exhaust analysis system and equip it with a set of analyzers (AVL AMA i60), 
- modernize the system of air and zero-calibration gases preparation so that it meats the requirements of the new devices.

Figure 2 shows the complete modernized test bed.

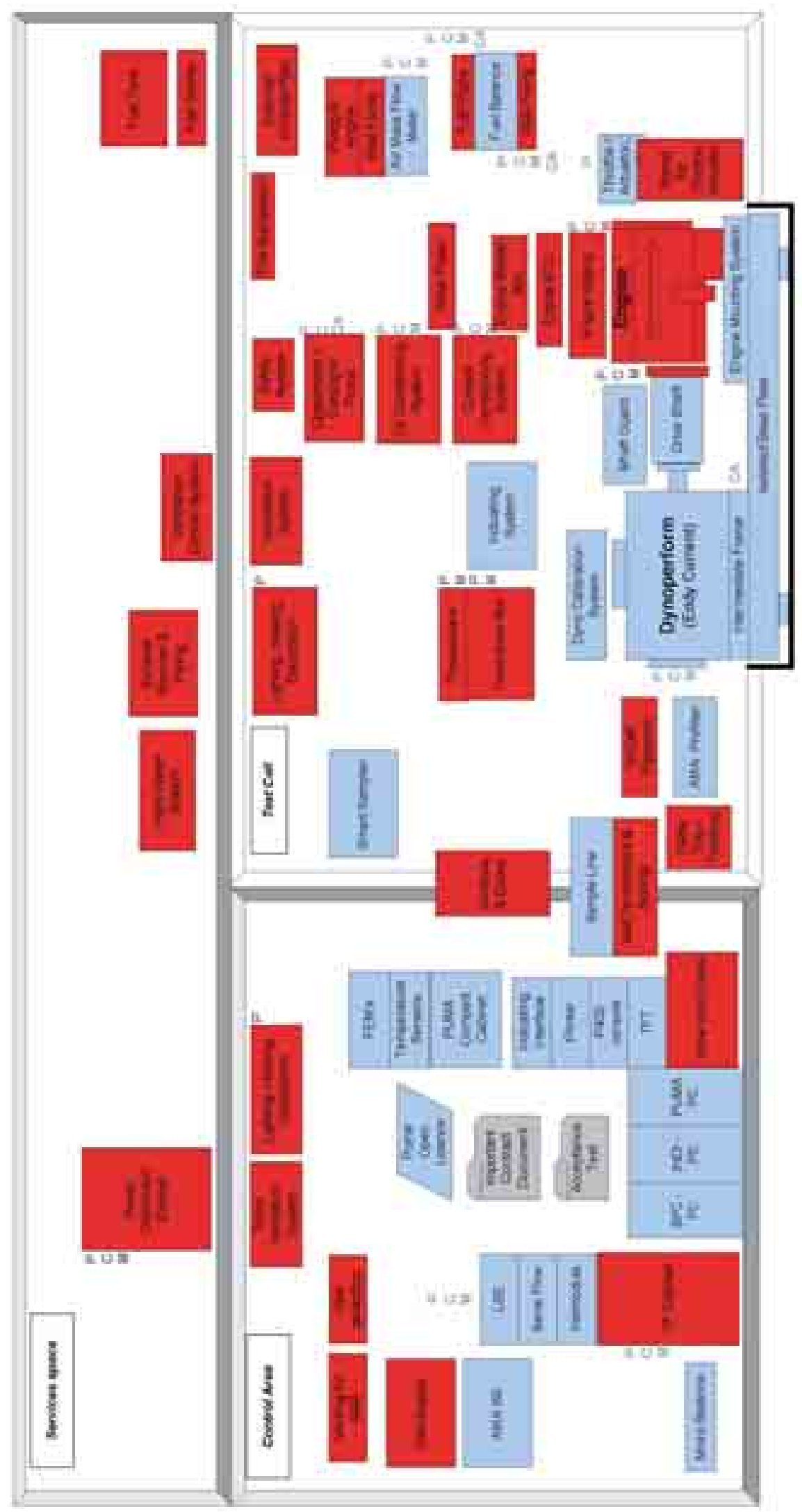

Fig. 2. A block diagram of the complete modernized test bed 
SPC 472 Smart Sampler is a flow tunnel to perform gravimetric measurements of particulate in exhaust gases. In the outlet total flow, only a little particle flow is led to the measurement tunnel and there it is diluted by compressed air. The dilution index and particle velocity are regulated by a control through signals from velocity sensors. Particle velocity equals here a total velocity in the outlet tunnel minus the diluting air velocity. Using such a measurement method, it is possible to imitate the CVS tunnel conditions, required by EEC 91/542 norm to measure particulate, at the same time reducing the size and the cost of the test bed. Moreover, it is possible to conduct measurements at any chosen dilution index.

AMA i60 emission analysis system in the new configuration comprises five analyzers measuring the concentration of THC, $\mathrm{CH} 4 \mathrm{NOx}, \mathrm{CO}, \mathrm{CO} 2$ in exhaust gases. The analyzers are put in one housing and communicate among each other through the internal CAN modules. When the system is appropriately installed and calibrated, it is fully automated and does not require any work on the part of the controller. It can work absolutely independently of the main system. It is equipped in its own industrial PC with a touch panel and keyboard, which ensures communication with the controller. In the present configuration, the device is compatible with the PUMA Open automated system through TCP/IP protocol, sending ready measurements to the main computer.

To function well, the whole test bed needs compressed air. It is used for instance to reduce vibrations and level the engine-brake system (the air-bag system) and as a medium to heat and clean ducts delivering exhaust gases to the opacimeter and Smart Sampler. Thus, the bed was equipped with a central system of preparing air, comprising an ABAC piston air compressor (PROFI 1210-11/500) and cleaning filters, which was a sufficient solution in the case of the above mentioned subsystems.

Starting the AMA i60 system necessitated delivering air of a definitely higher cleanliness class in order to assure proper function of analyzers. The analysis of applied solutions led to implementing an additional air drying system. It was decided to use an electric compressor, model ABC-12, which cooperated with absorption air dryer (D90IM, Ingersoll Rand). The preliminary and final filters which were delivered together with the drier and implemented guarantee the first class air acc. to ISO norms for particulate and oil. The dryer itself guarantees second cleanliness class acc to ISO when it comes to water content in the compressed air with the dew point at $-40\left[{ }^{\circ} \mathrm{C}\right]$, which complies with the norms for AMA i60 analyzers.

Moreover, the system of analyzers necessitated extending the special gas inlet system. It was essential to provide the control room with specialist gas mixtures under a determined pressure so that the system was able to function properly. Bottle reducers were applied, and gas was delivered to the control room, where a wall panel with cut-off valves was installed. From the panel, gases were delivered to the Span Gas Unit at the back of the test bed. The SGU module was responsible for dosing gases in appropriate proportions.

\section{The test engine}

Dual-feed systems for diesel engines will be further analyzed with reference to the ADCR type engine produced by Andoria-Mot Ltd. Andrychów, Poland. Tab. 1 presents basic parameters of this engine.

In order to adjust the engine to the test bed, first of all it was mounted onto the bed with special handles enabling the right connection between the engine and the brake plate (Fig. 3). Then, additional engine equipment was mounted, which comprised an intercooler, an accelerator and its connection with servomechanism of the brake unit, expansion tank, and ignition switch (whose connection was modified so that the engine could be controlled from the control panel). Circuit breakers and a set of indicators were mounted as well. 
Tab. 1. Technical data of an ADCR engine

\begin{tabular}{|l|l|}
\hline Engine & ADCR \\
\hline Type & diesel, 4-stroke, turbocharged with intercooler \\
\hline Fuel injection & Common Rail fuel accumulator system \\
\hline Engine layout & 4 cylinder inline, vertical \\
\hline Cylinder diameter / piston travel & $94 / 95 \mathrm{~mm}$ \\
\hline Piston displacement volume & $2636 \mathrm{~cm} 3$ \\
\hline Compression ratio & $17.5: 1$ \\
\hline Rated power* / rotational speed & $85 \mathrm{~kW} / 3700 \mathrm{rpm}$ \\
\hline Max. torque* / rotational speed & $250 \mathrm{Nm} / 1800-2200 \mathrm{rpm}$ \\
\hline Min. idle rotational speed & $750 \mathrm{rpm}$ \\
\hline Fuel consumption at torque peak* & $210 \mathrm{~g} / \mathrm{kWh}$ \\
\hline Injection system (Bosch) & accumulator injection system (Common Rail) CR2.0 \\
\hline Turbocharger & radial, with exhaust extraction valve \\
\hline EGR system & pneumatic EGR valve with exhaust cooler \\
\hline
\end{tabular}
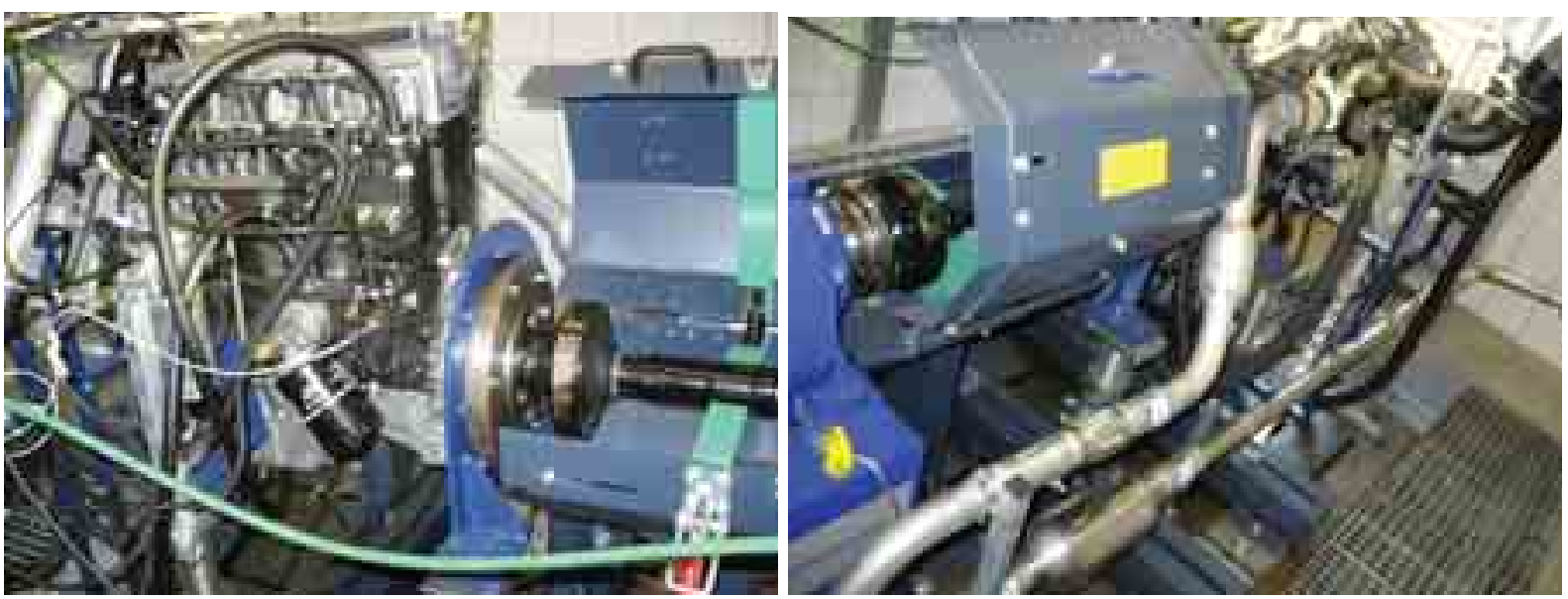

Fig.3. The ADCR engine on the test bed; The exhaust train of the ADCR engine mounted on the test bed

Subsequently, systems delivering air from the feed system of the brake unit to the engine were designed and constructed. Moreover, the exhaust system was adjusted taking into consideration requirements for exhaust analysis. Additional PT100 sensors were mounted in order to ensure performance parameters control with AVL Puma measurement system, since such sensors can measure temperatures of the cooling liquid and lubricating oil.

It was necessary to perform an exact alignment of the engine-shaft-brake system. When the engine started, series of vibration measurements were performed with a accelerometer sensor in different points of the brake. Vibrations did not exceed the permitted level, which confirms then the alignment was accurate.

Installing a new object necessitated calibrating the brake anew, implementing basic engine data and setting the alarm ranges and procedures in the PUMA Open system. In the present specification alarm thresholds were set to measure the temperature of the cooling liquid and lubricating oil, and a border rotational speed was set to protect the engine against uncontrolled over speeding when a researcher's own control algorithm is implemented.

\section{Results of preliminary ADCR engine tests}

The presented test bed enables comprehensive IC engine testing in line with the current norms. While the PUMA Open system controls measurements, it is possible to perform full-scale automated tests, which guarantees their accuracy. Monitoring most of the engine parameters 'on 
line' enables determining various characteristics of the analyzed engine. Fig. 4 presents a typical characteristic, which shows changes of $\lambda$ index - an air-fuel ratio - depending on the torque at constant rotational speed of the engine. Fig. 5 shows a characteristic of exhaust opacity at constant rotational speed and changing engine load. Fig. 6 presents a change in the engine filling efficiency depending on its load at constant rotational speed.

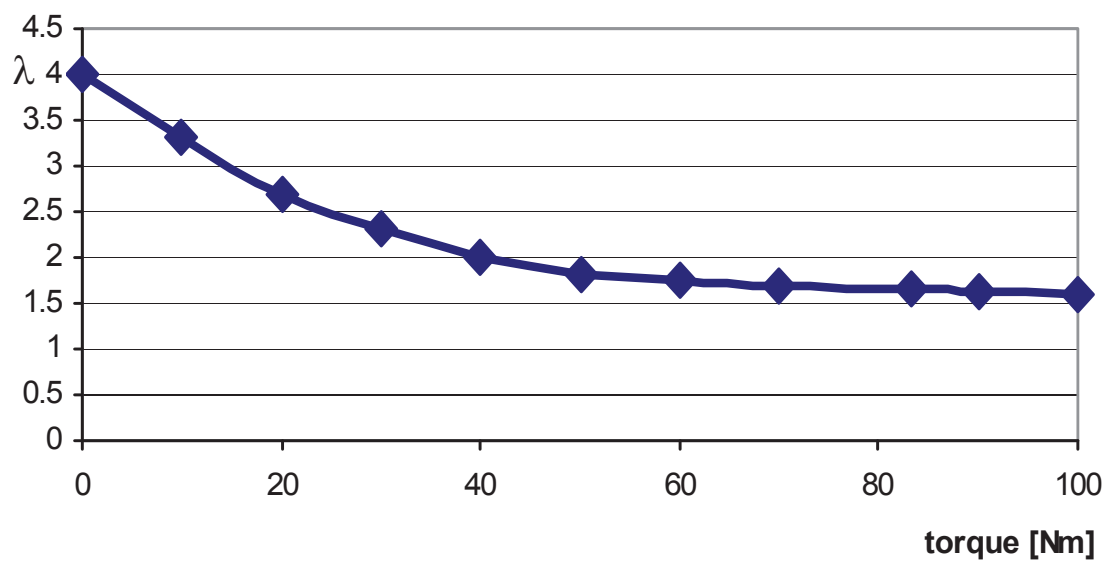

Fig. 4. Changes of the air-fuel ratio depending on the torque at constant rotational speed of the engine

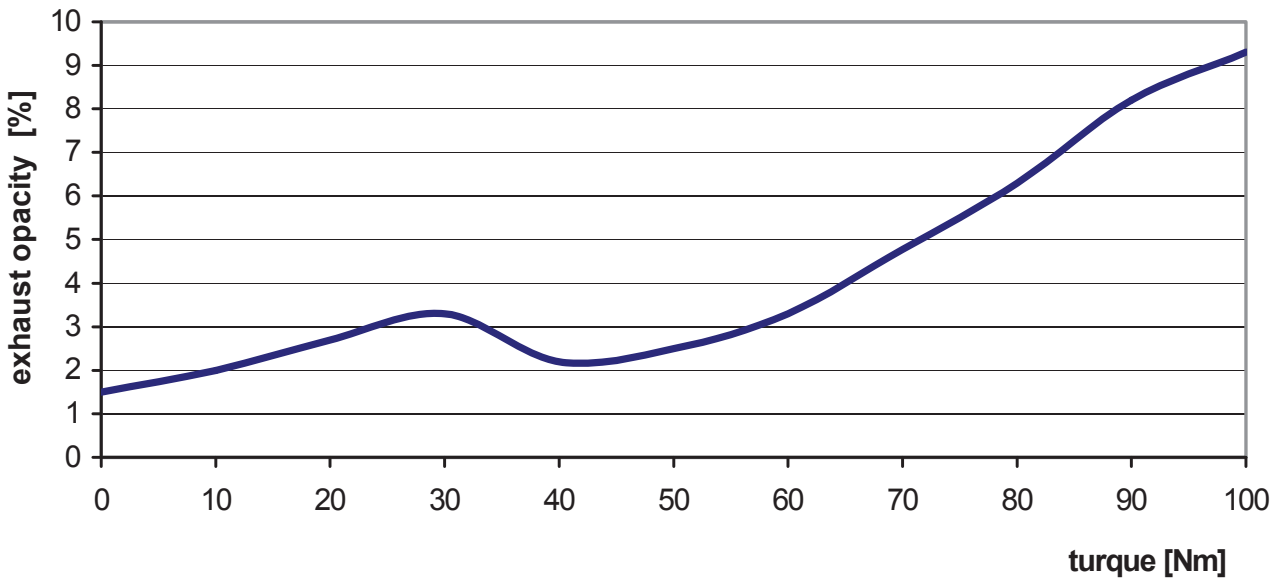

Fig. 5. Characteristics of exhaust opacity at constant rotational speed and changing engine load

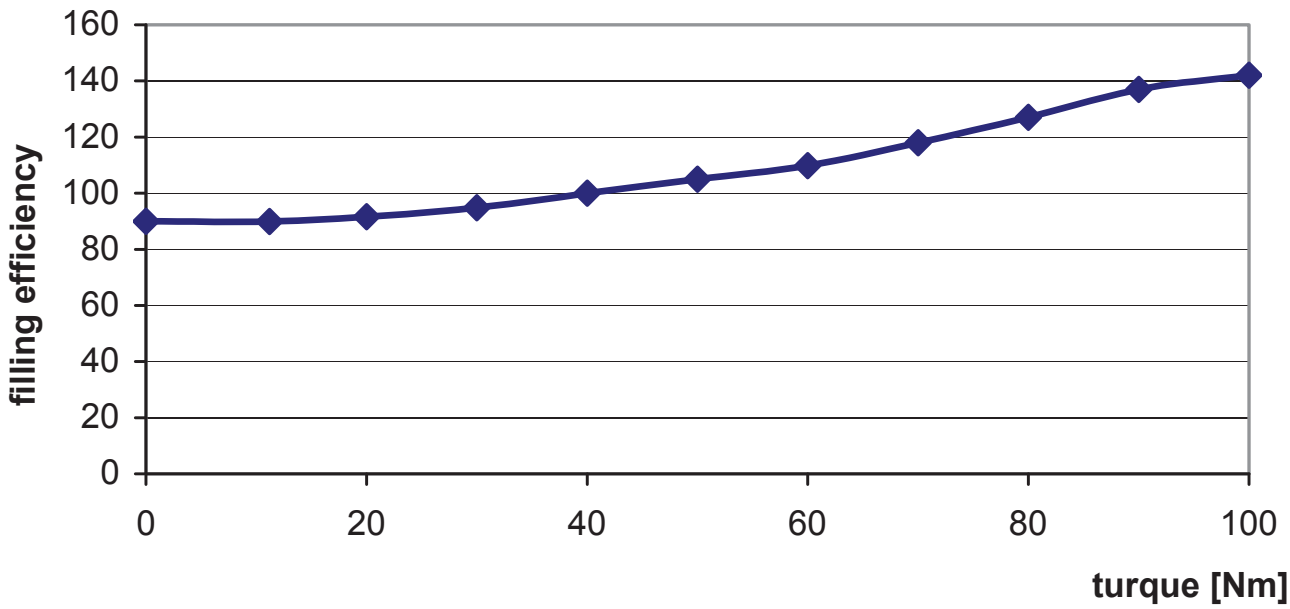

Fig. 6. Change in the engine filling efficiency depending on its load at constant rotational speed 


\section{Conclusion}

The test bed which was described above enables comprehensive research into internal combustion engines, while the AVL PUMA Open system enables automated testing of IC engines in line with the current engine tests. Thanks to an open software structure it is also possible to modify the existing tests as well as introducing a researcher's own ones. Automating the research makes it possible to compare the results since the tests are repeatable.

The constructed test bed enables research into the dual-fuel feed system in SC engines, both into their maximum power and torque, as well as effect of such feeding on toxic emissions into the atmosphere.

The test bed features a system (which was not described in this article) of heat recovered from cooling system, which enables testing CI engines for cogeneration systems. Additionally, the gaseous fuel feed system is built so that it enables testing with the use of biogas as an alternative fuel in Diesel engines.

\section{References}

[1] Alla, G. H. A, Soliman, H. A., Badr, O. A., Rabbo, M. F. A., Effects of pilot fuel quantity on the performance of dual fuel engine, Energy Conversion \& Management, 42, pp. 559-572, 2000.

[2] Czerwiński, J., Comte, P., Influences of Gas Quality on a Natural Gas Engine, Proceedings of the International Scientific Conference Development and Design of ice Engines and Quality of Fuels to Meet Future Levels, Kraków 2001.

[3] Gebert, K., Beck, J., Barkhimer, R. L., Wong, H. Ch., Strategies to improve Combustion and Emmison Characteristics of Dual-Fuel Pilot Ignited Natural Gas Engines, SAE Paper 971712, 1997.

[4] Kairm, G. A., An Examination of Some Measures for Improving the Performance of Gas Fuelled Engines at Light Load, SAE Paper 912366, 1991.

[5] Liu, Z., Karim, G. A., The Ignition Delay Period in Dual Fuel Engines, SAE Paper 950466, 1995.

[6] Mikulski, M., Problemy modelowania silników wielopaliwowych $w$ kontekście oceny parametrów pracy układu - Część I - wtrysk paliwa, Zeszyty naukowe Instytutu Pojazdów, $5(86) / 2011$.

[7] Motyl, K., Lisowski, M., Wpływ temperatury poczatkowej i sktadu mieszaniny palnej na prace silnika hcci zasilanego biogazem, Inżynieria Rolnicza 1(99)/2008.

[8] Piętak, A., Mikulski, M., On the modeling of pilot dose ignition delay in a dual-fuel, self ignition engine, Combustion Engines - PTNSS -2011-SC-162, 2011.

[9] Piętak, A., Wierzbicki, S., Imiołek, M., Mikulski, M., Dwupaliwowy silnik o zapłonie samoczynnym do zasilania biopaliwowych agregatów prądotwórczych, Journal of KONES, Vol. 16, No. 3, 2009.

[10] Piętak, A., Imiołek, M., Wierzbicki, S., Wielopaliwowy gazowy silnik o ZS jako pierwotne źródło energii. Cześć I. Cel badań i opis stanowiska, Silniki Gazowe - wybrane zagadnienia, seria Monografie nr 183, Wydawnictwo Politechniki Częstochowskiej, 2010.

[11] Piętak, A., Imiołek, M., Wierzbicki, S., Wielopaliwowy gazowy silnik o ZS jako pierwotne źródto energii, Cześć II, Wyniki badań wstęnych silnika Hatz 1B40, Silniki Gazowe wybrane zagadnienia, seria Monografie nr 183, Wydawnictwo Politechniki Częstochowskiej, 2010.

[12] Shijoi, M., Ishiyama, T., Ikegami, M., Mitani, S., Shibita H., Performance and Exhaust Emissions in a Natural-Gas Fueled Dual-Fuel Engine, JSME International Journal Series B Fluids and Thermal Engineering, Vol. 44, No. 4, pp. 641-648, 2001. 
[13] Stelmasiak, Z., Studium procesu spalania gazu $w$ dwupaliwowym silniku o zapłonie samoczynnym, Praca habilitacyjna. Wydawnictwo ATH, Bielsko-Biała 2003.

[14] Stelmasiak, Z., Combustion with low NOx and Smokeless in a Dual-Fuel Diesel Engine Fuelled with Natural Gas as Main Fuel, Journal of KONES Internal Combustion Engines, Vol. 11, No. 3-4, 2004.

[15] Stelmasiak, Z., Wpływ wielkości dawki inicjującej oleju napędowego na parametry pracy dwupaliwowego silnika zasilanego olejem napędowym i gazem ziemnym, Journal of KONES Powertrain and Transportation, Vol. 8, No. 3-4, 2000.

[16] Syed Kaleemuddin, Amba Prasad Rao, G., Development of dual fuel single cylinder natural gas engine an analysis and experimental investigation for performance and emission, American Journal of Applied Sciences 6 (5): 929-936, 2009.

[17] Yao, M., Zhang, Q., Zheng, Z., Zhang, P., Experimental study of effects of oxygen concentration on combustion and emissions of diesel engine, Sci China Ser E-Tech Sci, Jun, Vol. 52, No. 6, pp. 1527-1534, 2009.

[18] Zhang, Y., Liu, X., Yang, Q., Han, X., Cheng, Ch., The studies of electronically controlled CNG system for dual fuel engines, SAE Paper No. 2001-01-0145, 2001.
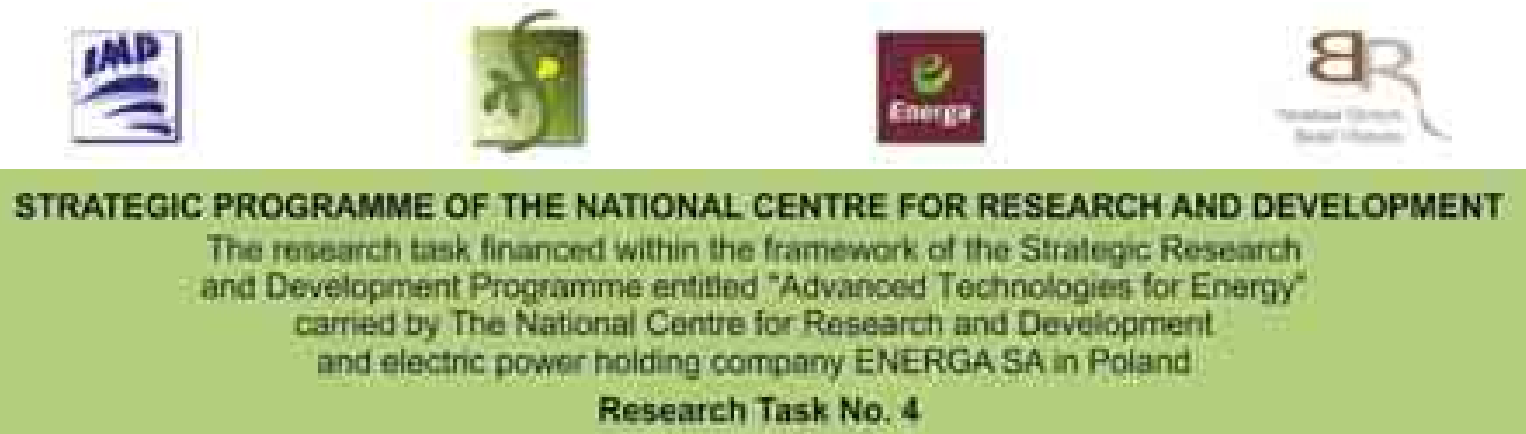

DEVELOPMENT OF INTEGRATED TECHNOLOGY OF FUELS AND ENERGY FROM BIOMASS, AGRICULTURAL WASTE AND OTHER 